\title{
PENGARUH RETURN ON ASSETS, DEBT TO EQUITY RATIO, PRICE EARNING RATIO DAN FIRM-SIZE TERHADAP NILAI PERUSAHAAN PADA PERUSAHAAN KATEGORI INDEKS LQ-45 DI BURSA EFEK INDONESIA
}

\author{
Triana Zuhrotun Aulia ${ }^{1}$ \\ Muhamad Riyandi ${ }^{2}$ \\ Program Studi Akuntansi, Fakultas Ekonomi dan Bisnis \\ Universitas Muhammadiyah Tangerang \\ tzahrotunaulia@gmail.com ${ }^{1}$ \\ muhamad.riyandi94@gmail.com²
}

\begin{abstract}
ABSTRAK
Price to Book Value (PBV) adalah rasio nilai pasar ekuitas terhadap nilai buku ekuitas. Price book value. adalah tingkat kemampuan untuk menciptakan nilai perusahaan relatif terhadap jumlah modal yang diinvestasikan. Penelitian ini akan menganalisis pengaruh return on asset, debt to equity ratio, price earning ratio dan ukuran perusahaan terhadap price book value secara simultan dan parsial. Populasi yang digunakan adalah perusahaan yang tergabung dalam indeks LQ-45 yang konsisten terdaftar di Bursa Efek Indonesia pada periode 2012-2016. Metode purposive sampling digunakan untuk mendapatkan sampel dan terpilih 18 perusahaan atau 72 firm-years. Analisis data menggunakan regresi linier berganda. Alat analisis data menggunakan SPSS 23.0. Berdasarkan hasil uji parsial (uji t) pada tingkat riil $(\alpha)=5 \%$ dapat dilihat bahwa variabel return on assets, debt to equity ratio dan price earning ratio berpengaruh signifikan dan positif terhadap price book value. Sementara ukuran perusahaan tidak berpengaruh signifikan terhadap price book value.
\end{abstract}

Kata Kunci : Nilai Perusahaan, Price Book Value, Return on Asset, Debt to Equity Ratio, Price Earning Ratio, Ukuran Perusahaan.

\begin{abstract}
Price to Book Value (PBV) is the ratio of the market value of equity to the book value of equity. $P B V$ is the level of ability to create a company's value relative to the amount of capital invested. This study will analyze both simultaneous and partial effect of return on assets, debt to equity ratio, price earning ratio and firm-size to price book value. Companies classified in LQ45 selected as the population used in this study are listed on the Stock Exchange 2012-2016 period. Purposive sampling is used to get the sample in this research using criterias and 18 companies or 72 firm-years are the samples. Analysis tool in this research using spss 23.0. This research is using multiple linear regression. Based on the results of the partial test ( $t$ test) on the real level $(\alpha)=5 \%$ can be seen that the variabel return on assets, debt to equity ratio and price earning ratio have a significant and positive impact on price book value, meanwhile firm-size have no significant effect on price book value.
\end{abstract}

Keywords : Firm value, Price Book Value, Return on Asset, Debt to Equity Ratio, Price Earning Ratio, Firm-size. 


\section{PENDAHULUAN}

Perusahaan didirikan dengan maksud mencapai tujuan perusahaan baik jangka pendek maupun jangka panjang. Tujuan jangka pendeknya adalah perusahaan dapat memperoleh keuntungan yang semaksimal mungkin dengan pemanfaatan sumber daya yang dimiliki oleh perusahaan. Tujuan jangka panjang adalah memaksimalkan nilai perusahaan (Putra, 2014). Nilai perusahaan merupakan hasil dari kinerja perusahaan tersebut dalam satu periode. Semakin baik kinerja keuangan suatu perusahaan maka semakin mudah untuk menarik investor untuk menginvestasikan dananya untuk perusahaan. Karena diharapkan semakin baik kinerja suatu perusahaan maka nilai saham akan meningkat dan memberikan return yang diharapkan oleh investor.

Dengan semakin berkembangnya pasar modal di Indonesia menuju kearah yang efisien, semua informasi yang relevan bisa digunakan sebagai masukan bagi investor untuk menilai pergerakan harga saham sebagai dasar untuk keputusan investasinya. Investor akan cenderung lebih memilih perusahaan yang memiliki track record yang baik di pasar modal, salah satunya adalah perusahaan-perusahaan yang termasuk dalam Indeks LQ 45.Namun fenomena yang terjadi pada pasar modalIndonesia cukup mengejutkan yaitu harga saham perusahaan LQ 45 mengalami volatilitas yang cukup signifikan. Kondisi tersebut menyebabkannilai perusahaan mengalami kenaikan dan penurunan.

Beberapa perusahaan yang mengalami kenaikan harga sahamnya adalah PT ADHI (Adhi Karya Tbk,) yaitu sebesar Rp 1.970 dari harga awal sebesar Rp 1.510 menjadi Rp 3.480 pada akhir tahun 2014 (www.icamel.co.id). Kenaikan harga saham PT ADHI (Adhi Karya Tbk,) dikarenakan adanya komitmen pemerintah untuk memperbaiki infrastruktur di tanah air sehingga permintaan saham (demand) untuk perusahaan infrastruktur cenderung naik. Sedangkan pada perusahaan BUMI (Bumi Resources Tbk,) harga sahamnya mengalami penurunan sebesar Rp 189 dari harga awal sebesar Rp 269 menjadi Rp 80 pada akhir tahun 2014 (www.icamel.co.id). Penurunan harga saham BUMI (Bumi Resources Tbk,) dikarenakan pada tahun 2014 harga batubara mengalami penurunan (kemerosotan). Penurunan harga saham perusahaan Bumi Resources membuat nilai perusahaannya menjadi turun. Hal ini sangat mengejutkan calon investor, sehingga mereka lebih waspada, teliti dan hati-hati ketika ingin berinvestasi.

Dalam rangka meningkatkan nilai perusahaan, pihak manajemen perusahaan berusaha mengaplikasikan faktor-faktor yang dapat memaksimalkan nilai perusahaan. Salah satu faktor yang dapat meningkatkan nilai perusahaan adalah profitabilitas. Weston dan Copeland (1992) mendefinisikan profitabilitas, sejauh mana perusahaan menghasilkan laba dari penjualan dan investasi perusahaan. Apabila profitabilitas perusahaan baik maka para stakeholders yang terdiri dari kreditur, supplier, dan juga investor akan melihat sejauh mana perusahaan dapat menghasilkan laba dari penjualan dan investasi perusahaan. Dengan baiknya kinerja perusahaan akan meningkatkan pula nilai perusahaan (Prasetyorini, 2013). Selain profitabilitas, nilai suatu perusahaan juga dipengaruhi oleh DER (debt to quity ratio). DER (debt to quity ratio) mencerminkan kemampuan perusahaan dengan menggunakan seluruh kewajibannya yang ditunjukkan oleh beberapa bagian modal sendiri yang digunakan untuk membayar hutang. Oleh karena itu, semakin rendah DER (debt to equity ratio), semakin tinggi kemampuan perusahaan untuk membayar seluruh kewajibannya. Pada akhirnya peningkatan hutang akan mempengaruhi tingkat pendapatan bersih yang tersedia bagi pemegang saham termasuk dividen yang akan diterima (Frederik dkk, 2015).

Nilai perusahaan dapat pula dipengaruhi oleh price earning ratio. Price Earning Ratio dihitung dari perbandingan antara harga saham suatu perusahaan dengan laba per lembar saham. Faktor lain yang dapat menentukan nilai perusahaan adalah ukuran perusahaan. Ukuran perusahaan adalah suatu skala dimana dapat diklasifikasikan besar kecilnya perusahaan menurut berbagai cara antara lain dengan total aktiva, log size, nilai pasar saham, dan lain-lain. Semakin besar ukuran suatu perusahaan maka perusahaan dianggap semakin mudah untuk 
mendapatkan sumber pendanaan bagi operasional perusahaan. Semakin baik dan semakin banyaknya sumber dana yang diperoleh, maka akan mendukung operasional perusahaan secara maksimum, sehingga akan meningkatkan harga saham dari perusahaan. Oleh karena itu ukuran perusahaan dinilai dapat mempengaruhi nilai perusahaan.

\section{KAJIAN PUSTAKA DAN PENGEMBANGAN HIPOTESIS}

\section{Kajian Pustaka}

\section{a. Signalling Theory}

Teori sinyal mengemukakan tentang bagaimana seharusnya sebuah perusahaan memberikan sinyal kepada pengguna laporan keuangan. Sinyal ini berupa informasi mengenai apa yang sudah dilakukan oleh manajemen untuk merealisasikan keinginan pemilik. Informasi tersebut penting bagi investor dan pelaku bisnis karena informasi pada hakekatnya menyajikan keterangan, catatan atau gambaran, baik untuk keadaan masa lalu, saat ini maupun masa yang akan datang bagi kelangsungan hidup perusahaan dan bagaimana efeknya pada perusahaan (Septia, 2015). Signalling theory menjelaskan mengapa perusahaan mempunyai dorongan untuk memberikan informasi laporan keuangan pada pihak eksternal. Dorongan perusahaan untuk memberikan informasi karena terdapat asimetri informasi antara perusahaan dan pihak luar karenaperusahaan mengetahui lebih banyak mengenai perusahaan dan prospek yang akan datang daripada pihak luar (investor dan kreditur).

\section{b. Agency Theory}

Teori agensi mengasumsikan bahwa setiap individu (prinsipal dan agen) termotivasi oleh kepentingan diri sendiri sehingga muncul konflik. Pihak prinsipal mempunyai motivasi mengadakan kontrak dengan tujuan mensejahterakan dirinya, sedangkan agen termotivasi untuk memaksimalkan pemenuhan kebutuhan ekonomi dan psikologinya (Hutahuruk, 2011). Agen dalam menjalankan perusahaan yang di amanahkan oleh pemilik (principle) seharusnya berorientasi pada kemakmuran prinsipal melalui meningkatan nilai perusahaan, sebagai imbalannya manajer (agent) akan mendapatkan gaji, bonus atau kompensasi lainnya.

\section{c. Price Book Value (PBV)}

Price Book Value merupakan rasio perbandingan antara harga pasar saham dengan nilai buku per lembar saham. PBV menunjukkan seberapa jauh suatu perusahaan mampu menciptakan nilai perusahaan yang relatif terhadap jumlah modal yang diinvestasikan. Semakin tinggi nilai PBV maka semakin berhasil perusahaan menciptakan nilai bagi pemegang saham. Nilai perusahaan merupakan kondisi tertentu yang telah dicapai oleh suatu perusahaan sebagai gambaran dari kepercayaan masyarakat terhadap perusahaan setelah melalui suatu proses kegiatan selama beberapa tahun, yaitu sejak perusahaaan tersebut didirikan sampai dengan saat ini (Septia, 2015).

\section{d. Return on Asset (ROA)}

ROA merupakan ukuran efektifitas perusahaan dalam menghasilkan keuntungan dengan memanfaatkan aset tetap yang digunakan untuk kegiatan operasi. Semakin besar ROA menunjukkan kinerja perusahaan yang semakin baik, karena tingkat pengembalian investasi (return) semakin besar (Prapaska, 2012). Jika prospek perusahaan baik maka investor akan merespon positif dan nilai perusahaan akan meningkat.

\section{e. Debt to Equity Ratio (DER)}

Debt to equity ratio merupakan rasio yang membandingkan total utang dengan ekuitas (Kasmir, 2012:197). Rasio ini mengukur seberapa jauh perusahaan dibiayai oleh 
hutang, dimana semakin tinggi rasio ini menggambarkan gejala yang kurang baik bagi perusahaan. Semakin besar hutang dibanding modal sendiri semakin besar pula risiko keuangan yang akan dihadapi investor sehingga investor akan mensyaratkan tingkat keuntungan yang semakin tinggi. Penggunaan hutang yang tinggi akan menimbulkan beban tetap yang ditanggung perusahaan sehingga menurunkan laba perusahaan sehingga menurunkan nilai perusahan dimata investor.

\section{f. Price Earning Ratio (PER)}

PER merupakan indikasi penilaian pasar modal terhadap kemampuan perusahaan dalam menghasilkan laba/keuntungan potensial perusahaan di masa datang. Rasio ini menunjukkan seberapa banyak investor bersedia membayar untuk setiap laba yang dilaporkan (Brigham dan Houston, 2011). Price earning ratio adalah suatu rasio sederhana yang diperoleh dengan membagi harga pasar suatu saham dengan earning per share. Jika price earning ratio perusahaan tinggi berarti saham perusahaan dapat memberikan return yang besar bagi investor. Price earning ratio juga merupakan ukuran untuk menentukan bagaimana pasar memberi nilai atau harga pada saham perusahaan (Arisona, 2013)

\section{g. Ukuran Perusahaan}

Ukuran perusahaan adalah skala untuk menentukan besar kecilnya suatu perusahaan. Ukuran perusahaan dapat diukur dengan beberapa cara, antara lain total aktiva, total penjualan, dan jumlah karyawan yang bekerja diperusahaan (Purwanto, 2004) dalam (Wihardjo, 2014). Perusahaan besar mempunyai lebih banyak sumberdaya untuk meningkatkan nilai perusahaan karena memiliki akses yang lebih baik terhadap sumber informasi eksternal dibandingkan dengan perusahaan kecil.

\section{Pengembangan Hipotesis}

Penelitian yang dilakukan Pantow dkk (2015) membuktikan bahwa pertumbuhan penjualan berpengaruh positif tidak signifikan terhadap nilai perusahaan, ukuran perusahaan berpengaruh negatif tidak signifikan terhadap nilai Perusahaan, sedangkan ROA dan struktur modal berpengaruh positif signifikan terhadap nilai perusahaan. Penelitian lain dilakukan Putra (2014), hasil dari penelitian ini menyimpulkan bahwa return on asset, return on equity, dan pertumbuhan perusahaan berpengaruh positif pada nilai perusahaan. sedangkan earning per share dan debt to equity ratio tidak berpengaruh pada nilai perusahaan.

Prasetyorini (2013) meneliti pengaruh ukuran perusahaan, leverage, price earning ratio dan profitabilitas terhadap nilai perusahaan, dan memperoleh hasil bahwa ukuran perusahaan, price earning ratio dan profitabilitas berpengaruh terhadap nilai perusahan sedangkan leverage tidak berpengaruh terhadap nilai perusahaan. Selain itu, Prasetia., dkk (2014) melakukan penelitian mengenai pengaruh struktur modal, ukuran perusahaan dan risiko perusahaan terhadap nilai perusahaan. Hasil dari penelitiannya menyimpulkan bahwa struktur modal dan risiko perusahaan mempunyai pengaruh positif tidak signifikan terhadap nilai perusahaan. Sedangkan ukuran perusahaan mempunyai pengaruh positif signifikan terhadap nilai perusahaan.

Dari uraian diatas, maka hipotesis yang diajukan adalah :

$\mathrm{H}_{1}$ : ROA berpengaruh positif signifikan terhadap nilai perusahaan.

$\mathrm{H}_{2}$ : DER berpengaruh negatif signifikan terhadap nilai perusahaan.

$\mathrm{H}_{3}$ : PER berpengaruh positif signifikan terhadap nilai perusahaan.

$\mathrm{H}_{4}$ : SIZE berpengaruh positif signifikan terhadap nilai perusahaan.

\section{METODE PENELITIAN}

\section{Desain Penelitian}


Metode penelitian ini menggunakan metode asosiatif dengan pendekatan kuantitatif dengan tujuan menjelaskan hubungan kasual dan pengaruh antara variabel melalui pengujian hipotesis (Sugiyono, 2011:56). Metode pengumpulan data adalah dokumentasi. Data penelitian berupa data sekunder yaitu laporan keuangan perusahaan yang diperoleh dari situs resmi Bursa Efek Indonesia di www.idx.co.id. Dimensi waktu yang digunakan adalah cross sectional-time series. Populasi adalah seluruh perusahaan perusahaan yang masuk dalam indeks LQ 45 yang terdaftar di Bursa Efek Indonesia selama periode tahun 2012 hingga 2015. Pengambilan sampel menggunakan teknik purposive sampling dan diperoleh 18 perusahaan atau 72 firm-years. Unit analisisnya adalah perusahaan. Tehnik analisis data menggunakan binary logistic regression. Pengolahan data menggunakan SPSS versi 23.

\section{Definisi dan Pengukuran Variabel}

\section{a. Variabel Dependen}

Variabel dependen dalam penelitian ini adalah nilai perusahaan yang diwakili oleh nilai price to book value (PBV). Rasio price to book value (PBV) merupakan rasio yang digunakan untuk mengukur kinerja pasar saham terhadap nilai bukunya (Pantow., dkk, 2015). Perusahaan yang baik umumnya mempunyai rasio PBV di atas satu, yang menunjukkan bahwa nilai pasar saham lebih besar daripada nilai buku perusahaan. PBV dapat dihitung dengan rumus :

$$
\mathrm{PBV}=\frac{\text { Share Price }}{\text { Book } \text { Value per }- \text { share }}
$$

Sumber : Pantow, dkk (2015)

\section{b. Variabel Independen}

\section{a. Return On Asset (ROA)}

Return on Asset merupakan rasio profitabilitas yang digunakan untuk mengukur efektifitas perusahaan di dalam menghasilkan keuntungan dengan memanfaatkan aktiva yang dimilikinya (Sitanggang, 2013:29-30). ROA dapat diukur dengan formulasi sebagai berikut :

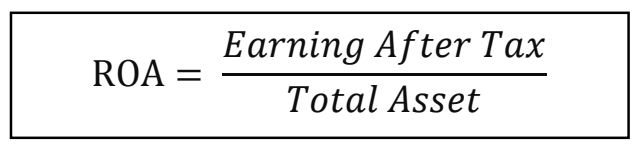

Sumber : (Sitanggang, 2013:29-30)

\section{b. Debt to Equity Ratio (DER)}

Debt to Equity Ratio merupakan ukuran yang dipakai dalam menganalisis laporan keuangan untuk memperlihatkan besar jaminan yang tersedia untuk kreditor. DER merupakan perbandingan antara total hutang yang dimiliki perusahaan dengan total ekuitasnya Harjito dan Martono (2012) atau dirumuskan sebagai berikut :

$$
\text { DER }=\frac{\text { Total Debt }}{\text { Total Equity }}
$$

Sumber : Harjito dan Martono (2012)

\section{c. Price Earning Ratio (PER)}

Price Earning Ratio d Price earning ratio adalah suatu rasio harga pasar saham dibandingkan dengan keuntungan per-lembar saham (earning per share). Dapat dihitung dengan formulasi sebagai berikut :

$$
P E R=\frac{\text { Share Price }}{\text { Earning per Share }}
$$


Sumber : Harjito dan Martono (2012)

\section{d. Ukuran perusahaan (SIZE)}

Ukuran perusahaan Ukuran perusahaan merupakan cerminan total dari aset yang dimiliki suatu perusahan. Perusahaan sendiri dikategorikan menjadi dua jenis, yaitu perusahaan berskala kecil dan perusahaan berskala besar diukur berdasarkan persamaan berikut ini:

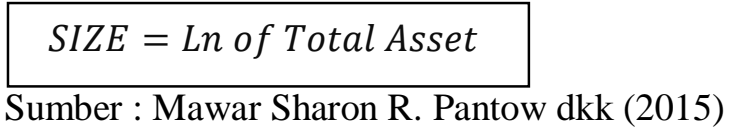

\section{Metode Analisis Data}

Metode analisis data yang digunakan terdiri dari analisis statistik deskriptif, uji asumsi klasik, analisis regresi dan uji hipotesis.

\section{a. Analisis Statistik Deskriptif}

Analisis statistik deskriptif memberikan gambaran atau deskripsi suatu data (variabel) yang dilihat dari nilai rata-rata (mean), standar deviasi, minimum, dan maksimum (Ghozali, 2013).

\section{b. Uji Asumsi Klasik}

Uji asumsi klasik digunakan untuk mengetahui apakah hasil analisis regresi linier berganda yang digunakan untuk menganalisis dalam penelitian ini terbebas dari penyimpangan asumsi klasik yang meliputi uji normalitas, multikolonieritas, autokorelasi dan heteroskedastisitas.

\section{c. Uji Koefisien Determinasi}

Koefisien Determinasi (R-square) menjelaskan variasi variabel independen terhadap variabel dependennya. Besarnya nilai koefisien determinasi adalah antara nol sampai dengan satu. Nilai koefisien determinasi dapat diukur oleh nilai Rsquare atau Adjusted Rsquare. Jika nilai koefisien determinasi suatu model mendekati satu, berarti variabel independen dapat memberikan hampir semua informasi yang dibutuhkan untuk menerangkan variasi pada variabel dependen (Ghozali, 2016).

\section{d. Uji F}

Uji F (uji simultan) digunakan untuk menguji apakah model regresi yang diestimasi layak (andal) atau idak.Model regresi yang layak (fit) artinyamodel yang diestimasi layak digunakan untuk menjelaskan pengaruh variabel-variabel bebas terhadap variabel terikat (Ghozali,2013). Adapun kriteria pengambilan keputusan sebagai berikut:

$\mathrm{H}_{0}=$ Model tidak fit,

$\mathrm{Ha}=$ Model fit,

Apabila nilai $\mathrm{F}$ hitung $<\mathrm{F}$ tabel dan nilai probabilitas $\mathrm{F}<0,05$, maka Ha diterima Apabila nilai $\mathrm{F}$ hitung $>\mathrm{F}$ tabel dan nilai probabilitas $\mathrm{F}>0,05$, maka Ha ditolak

\section{e. Uji Hipotesis (Uji T)}

Uji hipotesis ini dilakukan untukmengetahui ada/atau tidaknya pengaruhvariabel bebas dengan variabel terikatnya secara parsial. Pengujian inidilakukan dengan cara membandingkanantara tingkat signifikansi t dari hasilpengujian dengan nilai signifikansi yang digunakan dalam penelitian ini. Cara uji hipotesis parsial yang digunakan dalam penelitian ini adalah sebagai berikut :

$\mathrm{H}_{0}=$ Variabel bebas tidak berpengaruh signifikan terhadap variabel terikat $\mathrm{Ha}=$ Variabel bebas berpengaruh signifikan terhadap variabel terikat 
Kriteria pengambilan keputusan adalah :

Apabila nilai thitung $>\mathrm{t}$ tabel dan nilai prob. $\mathrm{t}$ hitung $<0,05$, maka Ha diterima

Apabila nilai thitung $<$ tabel dan nilai prob. $\mathrm{t}$ hitung $>0,05$, maka Ha ditolak

\section{f. Analisis Regresi Linier Berganda}

Penelitian ini menggunakan teknik analisis regresi linier berganda karena variabel independen dalam penelitian lebih dari dua. Teknik ini digunakan untuk mengetahui hubungan dan seberapa besar pengaruh antara variabel-variabel bebas (independen) terhadap variabel terikat (dependen).Persamaan regresi berganda yang digunakan dalam penelitian ini adalah :

$$
\text { PBV }=a+\beta_{1} \text { ROA }+\beta_{2} \text { DER }+\beta_{3} \text { PER }+\beta_{4} \text { SIZE }+\varepsilon
$$

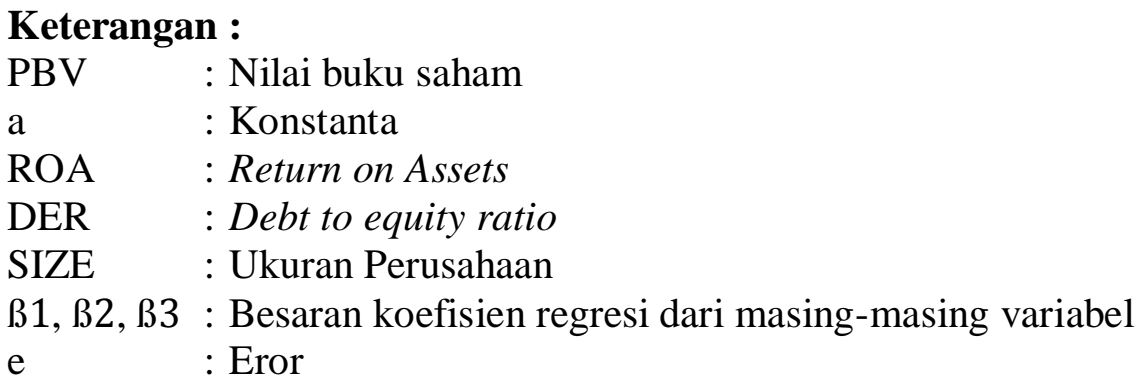

\section{HASIL DAN PEMBAHASAN}

\section{Analisis Statistik Deskriptif}

Tabel 1. Deskripsi Variabel Penelitian

\begin{tabular}{|l|r|r|r|r|r|}
\hline & N & \multicolumn{1}{c|}{ Minimum } & Maximum & Mean & \multicolumn{1}{c|}{ Std. Deviation } \\
\hline PBV & 72 & 1.02 & 9.30 & 3.2782 & 1.62636 \\
ROA & 72 & .02 & .23 & .1110 & .05547 \\
DER & 72 & 0.16 & 1.97 & .8021 & .47573 \\
PER & 72 & 5.12 & 44.61 & 18.9736 & 7.84896 \\
SIZE & 72 & 29.65 & 33.13 & 31.0621 & .88358 \\
Valid N & 72 & & & & \\
(listwise) & & & & \\
\hline
\end{tabular}

Sumber : Output SPSS 23.0

\section{Uji Asumsi Klasik}

Uji asumsi klasik bertujuan agar nilai parameter yang digunakan shahih dan tidak bias.

\section{a. Uji Normalitas}

Hasil uji normalitas Kolmogorov-Simirnov menghasilkan nilai statistik sebesar 0,773 dengan nilai Asymp.Sig. (2-tailed) sebesar 0,589. Hal ini menunjukkan bahwa nilai signifikansi lebih dari 0,05 (0,589>0,05), sehingga dapat disimpulkan bahwa residual menyebar normal dengan observasi sebanyak 72 data. Hasil ouput One-Sample Kolmogorov-Smirnov sebagai berikut :

\section{Tabel 2. Hasil Uji Normalitas}


One-Sample Kolmogorov-Smirnov Test

\begin{tabular}{|ll|r|}
\hline & & $\begin{array}{c}\text { Unstandardized } \\
\text { Residual }\end{array}$ \\
\hline $\mathrm{N}$ & Mean & 72 \\
Normal Parametersa, & Std. &, 0000000 \\
& Deviation &, 80549882 \\
& Absolute &, 091 \\
Most Extreme Differences & Positive &, 068 \\
& Negative &,- 091 \\
Kolmogorov-Smirnov Z & &, 773 \\
Asymp. Sig. (2-tailed) & &, 589 \\
\hline
\end{tabular}

Sumber : Output SPSS 23.0

\section{b. Uji Multikolonieritas}

Uji Multikolinieritas di seluruh variabel independen diperoleh nilai VIF kurang dari 10. Dan hasil perhitungan nilai tolerance pada setiap variabel mempunyai nilai lebih dari 0,10. Jadi dapat disimpulkan bahwa tidak terjadi multikolonieritas antar variabel independen dalam model regresi.

Tabel 3. Coefficients

Coefficients $^{\mathrm{a}}$

\begin{tabular}{|c|c|c|c|c|c|c|c|c|}
\hline & \multirow{2}{*}{ Model } & \multicolumn{2}{|c|}{$\begin{array}{l}\text { Unstandardized } \\
\text { Coefficients }\end{array}$} & \multirow{2}{*}{$\begin{array}{c}\text { Standardized } \\
\text { Coefficients }\end{array}$} & \multirow[t]{2}{*}{$\mathrm{t}$} & \multirow{2}{*}{ Sig. } & \multicolumn{2}{|c|}{$\begin{array}{l}\text { Collinearity } \\
\text { Statistics }\end{array}$} \\
\hline & & B & Std. Error & & & & Tolerance & VIF \\
\hline \multirow{5}{*}{1} & (Constant) & $\begin{array}{r}1.48 \\
9\end{array}$ & 3.754 & & .397 & .693 & & \\
\hline & ROA & $\begin{array}{r}24.4 \\
00\end{array}$ & 2.577 & .412 & 9.468 & .000 & .474 & 2.110 \\
\hline & DER & .848 & .294 & -.066 & 2.886 & .005 & .496 & 2.018 \\
\hline & PER & .132 & .013 & & 10.052 & .000 & .914 & 1.094 \\
\hline & SIZE & -.132 & .116 & -.303 & -1.136 & .260 & .896 & 1.089 \\
\hline
\end{tabular}

a. Dependent Variable: PBV

Sumber : Output SPSS 23.0

c. Uji Autokorelasi

Tabel 4. Model Summary

Model Summary ${ }^{\text {b }}$

\begin{tabular}{|c|c|c|c|c|c|}
\hline Model & $\mathrm{R}$ & $\begin{array}{c}\mathrm{R} \\
\text { Square }\end{array}$ & Adjusted R Square & $\begin{array}{c}\text { Std. Error of } \\
\text { the Estimate }\end{array}$ & Durbin-Watson \\
\hline 1 & $.869^{\mathrm{a}}$ & .755 & .740 & .82920 & 2.084 \\
\hline
\end{tabular}

a. Predicto8s: (Constant), ROA, DER, PER, SIZE

Sumber : Output SPSS 23.0

Dari tabel model summary diatas menunjukkan bahwa nilai Durbin-Watson (DW) sebesar 2,084. Nilai ini akan dibandingkan dengan nilai pada tabel DW pada level signifikansi 0,05. Jumlah sampel 72 (n) dan jumlah variabel sebanyak 5 (k-1); $\mathrm{k}=4$, maka pada tabel DW diperoleh nilai $\mathrm{n}=72, \mathrm{dL}=1,5029$, dan $\mathrm{dU}=1,7366$.

Karena DW terletak antara dU dan 4-dU (dU < DW < 4-dU) $=1,7366<2,084<$ 2,2634 , maka dapat disimpulkan bahwa residual pada penelitian ini tidak mengandung autokorelasi baik positif maupun negatif. 


\section{d. Uji Heteroskedastisitas}

Dari hasil grafik Scatterplot menunjukkan data (titik-titik) menyebar secara merata di atas dan di bawah garis nol, tidak berkumpul di satu tempat, serta tidak membentuk pola tertentu. Dari hasil tersebut dapat disimpulkan bahwa tidak terjadiheteroskedastisitas pada model regresi dalam penelitian ini.

\section{Uji Koefisien Determinasi}

Dari tabel model summary diatas, diperoleh nilai Adjusted $R$ Square sebesar 0,740. Hal ini menunjukkan bahwa $74 \%$ variabel Price to Book Value (PBV) dapat dijelaskan oleh variabel Return on Asset (ROA), Debt to Equity Ratio (DER), Price Earning Ratio (PER) dan Ukuran Perusahaan (SIZE) dan sisanya sebesar $26 \%$ dipengaruhi oleh variabel lain yang tidak dijelaskan oleh model penelitian ini.

\section{Uji Statistik F (F-test)}

Uji F-statistik digunakan untuk menguji besarnya pengaruh dari seluruh variabel independennya secara bersama-sama (simultan) terhadap variabel dependennya. Hasilnya dapat dilihat pada tabel Anova berikut ini :

\section{Tabel 5. Tabel Anova}

\begin{tabular}{|c|c|c|c|c|c|c|}
\hline \multicolumn{7}{|c|}{ NOVA $^{b}$} \\
\hline \multicolumn{2}{|c|}{ Model } & $\begin{array}{l}\text { Sum of } \\
\text { Squares }\end{array}$ & df & Mean & $\mathrm{F}$ & Sig. \\
\hline \multirow{3}{*}{1} & Regression & 141.732 & 4 & 35.433 & 51.534 & $.000^{\mathrm{b}}$ \\
\hline & Residual & 46.067 & 67 & .688 & & \\
\hline & Total & 187.799 & 71 & & & \\
\hline
\end{tabular}

a. Predictors: (Constant), ROA, DER, PER, SIZE

b. Dependent Variable: PBV

Sumber : Output SPSS 23.0

Dari tabel uji F diatas, menunjukkan bahwa semua variabel independen berpengaruh positif dan signifikan terhadap nilai perusahaan.

\section{Uji Statistik $\mathbf{t}(\mathrm{t}-$ test)}

Berdasarkan uji t,variabel ROA, DER dan PER memiliki pengaruh positif dan signifikan terhadap Nilai Perusahaan. Sedangkan variabel SIZE tidak memiliki pengaruh negatifdan tidak signifikan terhadap Nilai Perusahaan.

Tabel 6. Tabel Hipotesis

\begin{tabular}{|l|r|r|r|r|l|l|}
\hline Model & $\mathrm{t}_{\text {hitung }}$ & $\mathrm{t}_{\text {tabel }}$ & $\mathrm{p}$ value & $\alpha$ & \multicolumn{2}{|c|}{ Hasil } \\
\hline ROA & 9,468 & 1,996 & 0,000 & 0.05 & Berpengaruh Positif & $>\mathrm{t}_{\text {tabel }}$ \\
& & & & & & \\
\hline DER & 2,886 & 1,996 & 0,005 & 0.05 & Berpengaruh Positif & $>\mathrm{t}_{\text {tabel }}$ \\
\hline PER & 10.052 & 1,996 & 0,000 & 0.05 & Berpengaruh Positif & $>\mathrm{t}_{\text {tabel }}$ \\
\hline SIZE & $-1,136$ & $-1,996$ & 0,260 & 0.05 & Tidak Berpengaruh & $<\mathrm{t}_{\text {tabel }}$ \\
\hline
\end{tabular}




\section{Analisis Regresi Linier Berganda}

Dari tabel coefficient di atas dapat ditulis persamaan regresi linier sebagai berikut:

$$
Y=1,489+24,400 X_{1}+0,848 X_{2}+0,132 X_{3}-0,132 X_{4}+\varepsilon
$$

Persamaan regresi linier berganda tersebut dapat diinterpretasikan sebagai berikut:

a. Nilai konstanta sebesar 1,489 menyatakan bahwa jika tidak ada pengaruh dari variabelvariabel bebas (ROA, DER, PER dan SIZE=0) maka nilai PBV sebesar 1,489.

b. Nilai koefisien regresi ROA sebesar 24,400 menyatakan apabila ROA naik 1 satuan dalam skala pengukuran sementara variabel independen lainnya konstan maka akan mempengaruhi kenaikan PBV sebesar 24,400.

c. Nilai koefisien regresi DER sebesar 0,848 menyatakan apabila DER naik 1 satuan dalam skala pengukuran sementara variabel independen lainnya konstan maka akan mempengaruhi kenaikan PBV sebesar 0,848.

d. Nilai koefisien regresi PER sebesar 0,132 menyatakan apabila PER naik 1 satuan dalam skala pengukuran sementara variabel independen lainnya konstan maka akan mempengaruhi kenaikan PBV sebesar 0,132.

e. Nilai koefisien regresi SIZE sebesar -0.132 menyatakan apabila SIZE naik 1 satuan dalam skala pengukuran sementara variabel independen lainnya konstan maka akan mempengaruhi penurunan PBV sebesar 0,132.

\section{Pembahasan}

\section{a. Pengaruh Return on Asset terhadap Nilai Perusahaan}

Berdasarkan hasil uji statistik t ( $\mathrm{t}$-test) bahwa variabel ROA berpengaruh positif dan signifikan terhadap Nilai Perusahaan.Penelitian ini sejalan dengan penelitian yang dilakukan olehMawar Sharon R. Pantow, Sri Murni dan Irvan Trang (2012). Hal ini mengindikasikan bahwa perusahaan yang baik memperoleh keuntunganmaksimal dengan total aktiva yang dimiliki perusahaan. Sehingga semakin besar kemampuan perusahaan untuk menutup investasi yang digunakan dan memungkinkan perusahaanuntukdapat membiayai investasinya dari dana yang berasal dari sumber internal yang tersedia dalam bentuk laba ditahan. Sehingga informasi ROA yang tinggi akan menjadi sinyal positif bagi investor yang dapat meningkatkan kemakmuran investor, karena tingkat pengembalian atau deviden akan semakin besar.

\section{b. Pengaruh Debt to Equity Ratio terhadap Nilai Perusahaan}

Berdasarkan hasil uji statistik $\mathrm{t}$ ( $\mathrm{t}$-test)bahwa variabel DER berpengaruh positif dan signifikan terhadap Nilai Perusahaan. Penelitian ini sejalan dengan penelitian yang dilakukan olehPriscilia Gizela Frederik, Sientje C. Nangoy dan Victoria N. Untu (2015). Hal ini mengindikasikan bahwa dengan semakin banyaknya hutang perusahaan, investor menganggap perusahaan mempunyai banyak kesempatan menggunakan modalnya untuk ekspansi atau pengembangan dengan harapan semakin berkembangnya perusahaan maka keuntungan bagi investor juga akan semakin naik sehingga investor tertarik untuk membeli saham perusahaan. Semakin naik harga saham berarti nilai perusahaan juga akan meningkat.

\section{c. Pengaruh Price Earning Ratio terhadap Nilai Perusahaan}

Berdasarkan hasil uji statistik $\mathrm{t}(\mathrm{t}$-test) bahwa variabel PER berpengaruh positif dan signifikan terhadap Nilai Perusahaan. Penelitian ini didukung olehBhekti Fitri Prasetyorini (2013). Hal ini sejalan dengan signalling theory, bahwa PER yang tinggi merupakan sinyal pertumbuhan pendapatan perusahaan dimasa yang akan datang. Sinyal tersebut akan ditanggap investor sebagai good news yang nantinya akan mempengaruhi 
persepsi investor terhadap kinerja perusahaan. Permintaan saham yang tinggi akan membuat para investor menghargai nilai saham lebih besar daripada nilai yang tercatat pada neraca perusahaan, sehingga PBV perusahaan tinggi dan nilai perusahaan pun tinggi.

\section{d. Pengaruh Ukuran Perusahaan terhadap Nilai Perusahaan}

Berdasarkan hasil uji statistik t (t-test) bahwa variabel Ukuran Perusahaan tidak berpengaruh negatif dan tidak signifikan terhadap Nilai Perusahaan.Penelitian ini sejalan dengan penelitian yang dilakukan oleh Mawar Sharon R. Pantow, Sri Murni dan Irvan Trang (2012). Hal ini mengindikasikan bahwa para investor membeli saham tanpa melihat atau mempertimbangkan ukuran perusahaannya, karena perusahaan dengan total aktiva yang besar belum tentu dapat membayar deviden (laba ditahan) dikarenakan aset yang menumpuk. Perusahaan lebih memper-tahankan laba dibandingkan membagikannya sebagai deviden, yang dapat mempengaruhi harga saham dan nilai perusahaan.

\section{SIMPULAN}

Hasil penelitian membuktikan bahwa nilai perusahaan yang di proki dengan Price Book Value (PBV) pada perusahaan yang tergabung dalam kategori Indeks LQ-45 dipengaruhi secara signifikan oleh ROA, DER, PER sedangkan ukuran perusahaan tidak berpengaruh negatif dan tidak signifikan terhadap Nilai Perusahaan. Hal ini menunjukkan bahwainformasi fundamental perusahaan berua ROA, DER dan PER yang baik/tinggi masih menjadi sinyal positif bagi investor dan para calon inverstor yang mengenai tingkat pengembalian yang semakin besar sehingga memberikan dampak meningkatnya nilai perusahaan.

Rekomendasi yang dapat diberikan untukpara investor sebaiknya memperhatikan variabel return on asset, debt to equity ratio dan price earning ratio sebagai bahan pertimbangan dalam pengambilan keputusan investasi. Hal ini dikarenakan variabel-variabel tersebut memberikan pengaruh positif dan signifikan terhadap nilai perusahaan yang dapat mengindikasikan kemakmuran bagi para pemegang saham.Bagi manajemen perusahaan, untuk meningkatkan nilai perusahaan dapat diperoleh dengan cara meningkatkan laba perusahaan dan pengelolaan sumber dana hutang yang baik.

Bagi peneliti selanjutnya menambahkan variabel atau melakukan perluasan penelitian, tidak hanya terbatas pada faktor-faktor di dalam laporan keuangan saja, tetapi juga faktor-faktor ekonomi makro seperti tingkat inflasi, pertumbuhan ekonomi, tingkat suku bunga, dan lain-lain yang belum dipertimbangkan dalam penelitian ini. Selain itu periode penelitian yang lebih lama dan memperbanyak jumlah sampel yang digunakan, sehingga akan diperoleh gambaran yang lebih baik tentang nilai perusahaan di Bursa Efek Indonesia serta menggunakan objek penelitian perusahaan manufaktur atau indeks lainnya.

\section{DAFTAR PUSTAKA}

Arifin, Ali. 2004. Membaca Saham. Yogyakarta: Andi

Bhekti Fitri Prasetyorini 2013. Pengaruh Ukuran Perusahaan, Leverage, Price Earning Ratio Dan Profitabilitas Terhadap Nilai Perusahaan. Jurnal Ilmu Manajemen. (Volume 1 Nomor 1 Januari 2013).

Brigham, Eugene F, dan Joel F, Houston. 2001.Manajemen Keuangan. Buku II.Jakarta : Erlangga. 
Dewi, Ayu Sri Mahatma dan Wirajaya, Ary 2013. Pengaruh Struktur Modal, Profitabilitas dan Ukuran Perusahaan Pada Nilai Perusahaan. E-Jurnal Akuntansi Universitas Udayana. 4.2 (2013): 358372.

Fau, Nia Rositawati. 2015. Pengaruh Struktur Modal, Pertumbuhan Perusahaan, Ukuran Perusahaan dan Profitabilitas Terhadap Nilai Perusahaan Pada Perusahaan Manufaktur yang Terdaftar di Bursa Efek Indonesia.Skripsi. Yogyakarta : Fakultas Ekonomi Universitas Negeri Yogyakarta.

Frederik , Priscilia Gizela, Sientje C. Nangoy dan Victoria N. Untu 2015. Analisis Profitabilitas, Kebijakan Hutang dan Price Earning Ratio Terhadap Nilai Perusahaan Pada Perusahaan Retail Trade yang Terdaftar di Bursa Efek Indonesia. Jurnal EMBA1242.(Vol.3 No.1 Maret 2015 : 1242-1253).

Ghozali, Imam. 2013. Aplikasi Analisis Multivariate Dengan Program IBM SPSS 21 Update PLS Regresi. Edisi 7. Semarang : Badan Penerbit Universitas Diponegoro.

Harahap, Sofyan Syafri. 2011. Teori Akuntansi. Edisi Revisi 2011. Jakarta : Rajawali Pers.

Harjito, Agus dan Martono. 2012. Manajemen Keuangan. Edisi Kedua. Yogyakarta : Ekonisia.

Husnan, S dan Pudjiastuti, E, 2004.Dasar-Dasar Teori Portofolio.Edisi kedua. Yogyakarta : AMP YKPN.

Jogiyanto, Hartono. 2000. Teori Portofolio dan Analisis Investasi. Edisi Kedua. Yogyakarta : BPFE UGM.

Kasmir. 2009. Pengantar Manajemen Keuangan. Jakarta : Kencana.

Keown, J. Arthur, et al. 2000. Dasar-Dasar Manajemen Keuangan.Jakarta : Salemba Empat.

Kieso, Donald E, Weygandt, Jerry J dan Warfield, Terry D. 2008. Akuntansi Intermediate. Edisi Keduabelas. Jakarta : Erlangga.

Nasehah, Durrotun. 2012. Analisis Pengaruh ROE, DER, DPR, Growth, Dan Firm Size Terhadap Price To Book Value (PBV) (Studi Kasus Pada Perusahaan Manufaktur yang Listed di BEI periode Tahun 2007-2010).Skripsi.Semarang : Fakultas Ekonomika dan Bisnis Universitas Diponegoro.

Martalina, Lifessy 2011. Pengaruh profitabilitas dan ukuran perusahaan terhadap nilai perusahaan dengan struktur modal sebagai variabel intervening. skripsi.Padang : Fakultas Ekonomi Universitas Negeri Padang.

Melewar, TC. 2008. Facets of Corporate Identity, Communications and Reputations. New York: Routledge.

Mulyadi. 2001. Akuntansi Manajemen. Jakarta : Salemba Empat.

Nuh, Muhammad dan Suhajar Wiyoto. 2011. Accounting Principles. Jakarta : Lentera Ilmu.

Oktaviani, Sari 2013. Pengaruh keputusan investasi, keputusan pendanaan dan kebijakan dividen terhadap nilai perusahaan. Management Analysis Journal. (ISSN 2252-6552, Vol.2 No.2, 2013).

Pantow, Mawar Sharon R, Murni, Sri dan Trang, Irvan 2015. Analisa Pertumbuhan Penjualan, Ukuran Perusahaan, Return On Asset, dan Struktur Modal Terhadap Nilai Perusahaan yang Tercatat di Indeks LQ 45. Jurnal EMBA. (Vol.3 No.1 Maret 2015: 961-971).

Prasetia, Ta'dir Eko, Tommy, Parengkuan dan S. Saerang Ivone 2014.Struktur Modal, Ukuran Perusahaan dan Risiko Perusahaan Terhadap Nilai Perusahaan Otomotif yang Terdaftar di BEI. Jurnal EMBA.(Vol.2 No.2 Juni 2014: 879-889). 
Prawoto, Agus Tri Basuki Nano 2016. Analisis Regresi Dalam Penelitian Ekonomi \& Bisnis. Jakarta : Rajawali Pres.

Putra, Nyoman Wedana Adi 2014.Pengaruh Faktor Fundamental Pada Nilai Perusahaan Sektor Telekomunikasi di Bursa Efek Indonesia. E-Jurnal Akuntansi Universitas Udayana. 8.3 (2014): 385-407.

Sartono, Agus. 2010. Manajemen Keuangan Teori dan Aplikasi. Yogyakarta : BPFE.

Septia, Ade Winda. 2015. Pengaruh Profitabilitas, Keputusan Investasi, Keputusan Pendanaan, dan Kebijakan Dividen Terhadap Nilai Perusahaan Pada Perusahaan Manufaktur yang Terdaftar di Bursa Efek Indonesia. Skripsi. Yogyakarta : Fakultas Ekonomi Universitas Negeri Yogyakarta.

Sudana, I Made. 2009. Manajemen Keuangan Teori dan Praktek. Surabaya: Airlangga University Press.

Sugiyono. 2013. Metode Penelitian Bisnis. Bandung : Alfabeta.

Sumarsan, Thomas. 2013. Sistem Pengendalian Manajemen. Edisi 2. Jakarta : PT. Indeks.

Suroto 2015. Pengaruh Keputusan Investasi, Keputusan Pendanaan dan Kebijakan Dividen Terhadap Nilai Perusahaan (Studi Empiris Pada Perusahaan Lq-45 yang Terdaftar di Bursa Efek Indonesia Periode Februari 2010-Januari 2015). Jurnal Ilmiah UNTAG Semarang. (ISSN : 2302-2752, Vol. 4 No. 3, 2015).

Weston, J. F. Dan Copeland T.E. 1998. Dasar-Dasar Manajemen Keuangan. Erlangga : Jakarta.

Wihardjo, Djoko Satrio. 2014. Analisis Faktor-Faktor Yang Mempengaruhi Nilai Perusahaan (Studi pada Perusahaan Manufaktur yang Terdaftar di BEI Tahun 2009-2011).Skripsi.Semarang : Fakultas Ekonomika dan Bisnis Universitas Diponegoro.

Wild, John, K.R. Subramanyam, dan Halsey, Robert F. 2005. Analisis Laporan Keuangan. Edisi Delapan. Buku Dua. Alih Bahasa: Yanivi dan Nurwahyu. Jakarta : Salemba Empat.

www.icamel.co.id.

www.idx.co.id. 